УДК 274/278.014.6(477)(045)

DOI https://doi.org/10.32837/apfs.v0i26.906

\author{
I. В. Кундеренко \\ ORCID ID: 0000-0002-6115-499X \\ магістр культурології, магістр богослов'я, \\ викладач біблійних дисииплін \\ Рівненської Духовної Семінарії та Акаделії
}

\title{
СОЦІОЛОГІЧНІ ТА ІМІДЖЕВІ ОСОБЛИВОСТІ ЗАБЕЗПЕЧЕННЯ ЯКОСТІ ОСВІТИ СЕРЕД ПРОТЕСТАНТСЬКИХ ЗАКЛАДІВ ВИЩОЇ ОСВІТИ
}

Постановка проблеми. Шлях, обраний Україною у зв'язку із приєднанням до Болонського процесу, передбачає інтеграцію до спільного європейського освітнього та наукового простору.

Більшість закладів вищої освіти України зі здобуттям незалежності мали пройти процес переосмислення та трансформації, винятком можна назвати лише новостворені ЗВО та так звані ПВНЗ. Духовна освіта, яка від початку мала певні відмінності від світської освіти, повинна була не лише сформувати власне розуміння освіти зі всіма іï̈ складниками, а й пройти складний шлях від маргіналізації до визнання духовної освіти.

Особливо цей досвід трансформування соціальної групи цікавий із соціологічної точки зору, оскільки духовні ЗВО, створені протестантами, за 30 років пройшли шлях від маргіналізації до повноправної участі в освітньому просторі України. Як приклад можна назвати створення власної установи з акредитації освітніх програм - громадську організацію «Євангельська акредитаційна теологічна асоціація» (далі - ГО «ЄАТА»), в минулому відому як «Євро-азійська теологічна асоціація» [8]. За задумом, ця установа виконує функції нереалізованого положення ст. 23 Закону України «Про вищу освіту».

Аналіз останніх досліджень i публікацій. 0. Українець [28] описує явище антиінтелектуалізму у суспільстві загалом. Д. Бінцаровський [1] вважає, що окремі напрями українських протестантів схильні до антиінтелектуалізму на світоглядному рівні. Натомість ми відстоюємо точку зору, що протестанти України не лише ніколи не мали класичного антиінтелектуалізму, але й подолали залишкові явища обережної взаємодії із суспільством. Прикладом цього можуть слугувати нещодавні вибори у місцеві ради, коли мером міста Рівне став ректор духовного закладу освіти.

Одним із перших дослідників духовної освіти в Україні, зокрема й серед протестантів. став Ю. Решетніков [23]. Англомовний дослідник С. Кавана [31] розкриває сутність і комерційний обсяг ринкового складника освіти загалом. Самоокупність освіти в українських реаліях здається чимось недосяжним, проте українські протестанти розбудували мережу закладів освіти, яка існує без дер- жавного фінансування та досягає значних успіхів. Успішність цих зусиль як виконання свого місійного покликання розглядає В. Синій [26] - ректор першого з протестантських ЗВО, який отримав необов'язкову для духовних закладів освіти ліцензію.

В окремих публікаціях ми частково розглядаємо певні соціологічні аспекти духовної освіти. Так, вже розглянуто питання щодо термінотворення та недискримінаційного звертання до таких закладів освіти з метою уникнення маркування та стигматизації [13], а також етапи повноцінного входження духовних ЗВО в освітній простір України $[14 ; 15]$.

Метою статті є виокремити соціологічні та іміджеві особливості забезпечення якості освіти серед протестантських закладів вищої освіти.

Виклад основного матеріалу дослідження.

Скорочений історичний огляд становлення духовної освіти в Україні. Протягом переслідувань усіх незгідних із комуністичним світоглядом з боку атеїстичної влади Радянського Союзу процес здобуття духовної (або богословської) освіти був украй складним, якщо взагалі можливим [3]. Можна констатувати, що усі наявні духовні ЗВО в їх сучасному вигляді є новими. Протягом радянського періоду певна неформальна, а у дійсності підпільна несистематична діяльність із навчання вірян проводилася практично у всіх релігійних громадах. Починаючи із 1991 року, чимало різних релігійних конфесій приступили до заснування власних закладів освіти [9]. Здебільшого усі ці духовні ЗВО засновували конфесії або деномінації самостійно і виключно для забезпечення власних потреб.

Однак навіть у роки обережної міжконфесійної взаємодії мали місце спроби імплементації спільних проектів між кількома конфесіями. Так, у 1991 року розпочав свою діяльність Донецький Біблійний Коледж, який згодом був перейменований у Донецький Християнський Університет [16]. До створення цього духовного ЗВО долучилися кілька протестантських церковних об'єднань. Із сумом можемо повідомити, що у 2014 році цей духовний заклад був змушений припинити свою діяльність у зв'язку із захопленням приміщень проросійськими (або російськими) бойовиками.

Перспективами розвитку духовної освіти скористалися не лише християни протестантського 
віровизнання, але й католики, православні та навіть віряни інших релігій. На початку 1990-х років у середовищі вірян-протестантів простежувалося кілька цікавих соціологічних явищ, розглянемо їх.

Перше явище: серед християн-протестантів виник шалений попит на духовне навчання, який супроводжувався тим, що з днів свого заснування духовні заклади вищої освіти зіткнулися із певним внутрішнім супротивом щодо доцільності навчання. На цьому, зокрема, акцентує увагу доктор наук С. Санніков - один із піонерів заснування духовних закладів вищої освіти в Україні [25] у проведеній із ним опитувальній бесіді. Пояснення цього явища є дуже розбіжними: від спроби клеймувати українських протестантів виявом антиінтелектуалізму до визнання обережного ставлення до взаємодії із суспільством, яке нещодавно демонструвало ворожість до спільноти віри загалом. Ми розглядаємо це в інших статтях [13; $14 ; 15]$.

Друге явище: духовна освіта, особливо серед протестантів, з початку свого існування не ставила перед собою за мету отримання державного визнання. Це було зумовлено низкою різних причин: 1) цілі, які переслідувало таке навчання, були внутрішніми для спільноти віри та не відповідали традиційним цілям освіти, 2) внаслідок нещодавніх недружніх дій з боку влади така можливість виглядала недосяжною, 3) освіта в Україні переживала кризу, пов'язану з їі переосмисленням 3 огляду на здобуття незалежності, 4) у більшості духовних 3ВО, які створили протестанти, відбулося певне наслідування кращого досвіду побудови духовної освіти в США. На початку 1990-х років таке наслідування не було цілісним: багато протестантських закладів освіти прагнули копіювати освітні стандарти США, проте управлінську модель або адаптували під конфесійні вимоги, або наближували до прийнятних в Україні форм.

Зазначимо, що більшість американських 3ВО, які прямо чи опосередковано брали участь у розбудові духовної освіти в Україні, мають подвійну акредитацію освітніх програм - незалежної богословської агенції та різновид державної. Для українських духовних 3ВО факт, що такі богословські школи мають ще й визнання духовної освіти на державному рівні, не був визначальним. Однак з урахуванням того, що велика кількість викладачів та управлінців, які нині працюють у сфері духовної освіти, уперше ознайомилися саме з такою конфігурацією духовної освіти, відокремленої від світської, ця дихотомія не зникла.

\section{Сучасний стан духовної освіти}

Ситуація істотно змінилася у 2016 році, коли при Міністерстві освіти України (далі - МОН) була створена Комісія з державного визнання документів про вищу духовну освіту [27]. До її складу увійшли представники Міністерства освіти і нау- ки України, Громадської ради з питань співпраці 3 церквами та релігійними організаціями, представники релігійних громад, а також вищих закладів освіти, які мали ліцензію на здійснення освітньої діяльності в галузі знань «Богослов'я» $[2 ; 6 ; 7 ; 22]$. Так, було ухвалено рішення, що духовна освіта (диплом), здобута на території України до 2018 року, може пройти процес визнання у $\mathrm{MOH}$.

Донедавна можна було стверджувати, що, на відміну від «західного світу», заклади вищої освіти в Україні, крім ПВНЗ, здебільшого фінансуються за рахунок бюджетних коштів. Звісно, це впливало на розуміння боротьби за репутацію та імідж, де, на наш погляд, така боротьба прирівнюється до боротьби за рейтинги в різних списках, боротьбу за вступників i, беручи до уваги зміни у фінансуванні, боротьбу за нього.

Відоме рішення Кабінету Міністрів України про встановлення індикативної собівартості контрактного навчання для державних університетів та тих приватних, які отримуватимуть державне фінансування. Зацікавлені сторони можуть по-різному оцінювати таке рішення. Є. Стадник (свого часу заступник профільного міністра), наприклад, вважає, що це рішення дозволить підвищити якість освіти у закладах вищої освіти [10].

В сучасних умовах багато потенційних замовників освітніх послуг звертають увагу на різні рейтинги 3ВО. Оскільки серед протестантських конфесій України не складаються рейтингові списки 3ВО, ми не будемо застосувати цей підхід до нашого дослідницького поля.

Дослідниця М. Зацерківна виокремлює дев'ять елементів іміджу вищого освітнього закладу: 1) якість освіти; 2) керівник вищого освітнього закладу; 3) стиль 3ВО; 4) атрибутика освітнього закладу; 5) освітні послуги; 6) рівень психологічного й фізичного комфорту учасників освітнього процесу; 7) образ персоналу, який засвідчує найхарактерніші для нього якості; 8) участь 3 ВО у громадській діяльності; 9) згадування у ЗМІ [9].

Нам не вдалося знайти жодної вітчизняної наукової праці, яка б зосереджувалася на іміджі чи репутації власне духовних закладів вищої освіти, створених протестантами України. Тому ця тема $є$ не лише актуальною, але й має величезний потенціал для наукової новизни.

О. Панич зазначає, що згідно із наявною практикою отримання державної акредитації серед оцінювання процесів, результатів і ресурсів багато уваги звертається на показники ресурсів. Зрозуміло, що досягнення високих результатів не можливе без певних ресурсів і процесів [20; 21]. Ми констатуємо, що після 1991 року вітчизняна духовна освіта набула масштабного розвитку. Серед духовних закладів освіти домінують протестантські. Прикладом є те, що майже 100 із 230 духовних 3ВО, про які йдеться у листі МОН 
України від 5 липня 2018 року [30], можна назвати протестантськими.

\section{Соиіологічні особливості духовної освіти}

Перша особливість полягає у досить високій конкуренції, оскільки існує понад 200 духовних закладів освіти.

Друга особливість полягає у більшій вмотивованості студентів духовних закладів освіти, оскільки навчання, яке дає знання і вміння, потрібне для здебільшого безоплатного виконання християнського служіння і жодним чином не покращить матеріальний стан. До того ж більшість студентів духовних закладів освіти несуть спеціалізоване служіння у місцевих громадах. Наприклад, студенти, які вивчають «Богословські основи музичного служіння» у своїх релігійних громадах займаються музичним служінням; студенти факультетів церковного служіння у помісних релігійних громадах здійснюють проповідницьке служіння. Тобто вони здобувають освіту не для впевненого фінансового майбутнього, а навчаються, оскільки усвідомлюють його практичну потребу для громад.

Третя особливість полягає у світоглядних цінностях, здебільшого притаманних працівникам, викладачам, управлінцям і студентам духовних закладів освіти, що зумовлено розумінням певного Божого покликання до духовної праці, яке вимагає сумлінного ставлення до своїх обов'язків, зокрема й студентських; це те, що в західній богословській традиції має назву “vocatio".

Додатковим викликом, який стоїть перед керівниками духовних закладів освіти, є специфічні конфесійні аспекти, які суттєво впливають на керівні процеси забезпечення якості.

Перший аспект - конфесійні вимоги. Оскільки деномінації або конфесії здебільшого є засновниками або співзасновниками духовних закладів освіти, тому вони прямо чи опосередковано підпорядковані конфесійним структурам. Рівень адміністративного, кадрового, фінансового та управлінського впливів конфесії може бути різним. Він залежить від низки факторів, зокрема лідерських навичок та особистої харизми керівників закладів освіти.

Розглянемо два духовних навчальних заклади, які мають певні спільні риси (розташовані в одному місті, мають однакову конфесійну спрямованість і підпорядкування): Київська Богословська Семінарія [11], підпорядкована ВСЦ ЄХБ [4], і Київський Християнський Університет [12], підпорядкований ВСЦ ЄХБ. Київська Богословська Семінарія за роки існування мала лише двох ректорів, які були харизматичними лідерами та мали власне бачення i, незважаючи на конфесійну підпорядкованість, мали певну самостійність у побудові всіх процесів навчання та керування навчальним закладом, власне розуміння досягнення результату. Вони швидко та вчасно реагували на «конфесійні потреби» або «суспільні запити», зокрема, відмовившись від денної форми навчання. Самостійний пошук ресурсів також відігравав свою роль. Цей заклад вищої освіти серед українських баптистів є авторитетним.

Київський Християнський Університет мав більшу залежність від конфесії у призначенні керівництва навчального закладу, а також повільнішу реакцію на потреби «споживачів» послуг, він пережив кілька криз і практично припинив своє існування [17]. У закладі була стратегія розвитку, матеріально-технічна база - власні приміщення, бібліотека, яка мала наукові періодичні видання. Проте особливістю цього навчального закладу була надзвичайно повільна реакція на потреби споживацького ринку. Більшість духовних закладів почали відмовлятися від очної форми навчання, бачення КХУ передбачало здобуття ліцензування у віддаленій перспективі та впровадження спільних програм зі світськими вишами у найближчій. Якісний освітній процес мав ідентичну іншому духовному навчальному закладу оцінку, проте суттєвою відмінністю була відсутність харизматичного керівника, який би «жив» навчальним закладом. Структурно, процесно та ресурсно обидва заклади подібні.

Відомі випадки, коли окремі протестантські конфесії ставили перед навчальними закладами додаткові завдання. Наприклад, Рівненський обласний союз церков християн віри євангельської-п'ятидесятників свого часу виніс рекомендаційне рішення [19] про те, що пастори місцевих церков мають пройти духовне навчання, щоб продовжити своє служіння пастором. Фінансові ресурси мали походити від власних коштів пасторів або громад; кадрові ресурси мав забезпечити заклад вищої освіти.

Управлінська складність полягала у тому, що серед пасторів виник внутрішній супротив проти нав'язування керівництвом ідеї обов'язкового навчання, проте ті ж пастори не лише мали дати оцінку новоствореним навчальним програм пришвидшеного навчання, за якими ї навчали, а й від їхньої прихильності залежало подальше існування семінарії, оскільки пастори місцевих громад є стейкхолдерами духовної освіти. Задоволення цих очікувань дорівнює подальшому направленню студентів на навчання. Варто зазначити, що у цьому навчальному закладі рекомендація пастора місцевої громади є вимогою для вступу в заклад вищої освіти.

Другий аспект - конфесійні очікування. Очікування (аспіраціі) можуть бути загальноконфесійними, тобто притаманними усій деномінації чи конфесії, локальними, тобто властивими певній соціальній, зокрема віковій групі, всередині конфесії.

Християнська віра у практичному вимірі здебільшого мотивує протестантів до сумлінного 
виконання своїх обов'язків. Це явище описав М. Вебер у праці «Протестантська етика та дух капіталізму». Базовим світоглядним переконанням протестантських християн $є$ вірування у те, що людина має онтологічну цінність.

Особливу роль у духовній освіті відіграють керівники релігійних громад (пастори місцевих церков). Вони можуть виступати «замовниками» освітніх послуг, оскільки рекомендація пастора є умовою для вступу до більшості духовних закладів. Внаслідок конфесійної приналежності більшості протестантських закладів освіти пастори мають прямий та опосередкований вплив на управління завдяки участі в конфесійному управлінні. У протестантських духовних навчальних закладах певною мірою трансформується «виховний» складник, оскільки студенти мають не лише окреслені конфесійно-світоглядні переконання, але й саме навчання слугує доказом певного рівня посвяти.

\section{Немаргінальні "маргинали»}

Аналіз доступної вітчизняної літератури щодо явища антиінтелектуалізму серед протестантських церков і вірян демонструє помітну розбіжність серед оцінок дослідників щодо 1) природи антиінтелектуалізму, 2) витоків і причин цього феномену, 3) поширення цього явища.

Д. Бінцаровський наголошує на теологічних причинах [1] дистанціювання окремих вітчизняних протестантів від активної участі в житті суспільства, що часто призводить до свідомого відкидання інтелектуального життя як вияву невірності або світськості. О. Висоневець говорить про штучним чином створені умови, коли радянська влада не допускала вірян-протестантів до здобуття вищої освіти [3].

М. Черенков констатує, що вітчизняні протестанти здійснили перехід від маргінальності до свідомої соціалізації в пострадянському та постхристиянському суспільстві [29], передбачивши певні процеси, зокрема визнання духовної освіти. О. Українець доходить висновків, що як світовому, так і українському суспільству притаманний антиінтелектуалізм [28], тому твердження, що це явище притаманне лише протестантський спільності, є необ'єктивним і може містити ознаки стигматизації та упередженого маркування. У своїй дисертації, дослідницьким полем якої був п'ятидесятницький рух, М. Мокієнко згадує антиінтелектуалізм як явище, ознаки якого можна знайти серед окремих протестантів України [16].

Ми схильні вважати, що доведеним є лише факт історично зумовленого антагонізму між українськими протестантами і репресивним радянським устроєм та вияви цього явища у сучасному церковному середовищі як спадок від попередніх поколінь, який зовні набуває певних форм, що мають ознаки антиінтелектуалізму. Ми вважаємо, що не можливо реконструювати витоки явища українського протестантського антиінтелектуалізму, напрацювати інструмент розмежування загальносуспільного антиінтелектуалізму та власне протестантського.

Спробуємо обгрунтувати цю точку наведеними нижче міркуваннями6

1. Існування схем репресивних дій стосовно християн-вступників у виші та християн-здобувачів вищої освіти протягом нещодавнього часу доводить, що серед християн-протестантів зустрічалися систематичні спроби здобуття вищої освіти.

2. У найчисленнішій протестантській конфесії України - Всеукраїнському союзі церков євангельських християн-баптистів (далі - Союз) діє кілька духовних ЗВО. Таврійській Християнській Інститут [24], зокрема, обрав шлях ліцензування в МОН і став частиною освітнього простору України. Інші духовні ЗВО, засновані Союзом, не ухвалили остаточного рішення щодо ліцензування закладу освіти й акредитації освітніх програм.

3. Активна участь протестантів у місцевих виборах 2020 року, коли, наприклад, мером Рівного став представник протестантської спільноти, демонструє те, що протестанти є активною частиною суспільства.

Тому ми не можемо однозначно та безапеляційно стверджувати, що всім протестантам України притаманний антиінтелектуалізм, зумовлений віруванням. Ми не маємо засобів виміряти власне протестантський антиінтелектуалізм та оцінити поширення цього явища. Додамо, що ретроспективний огляд ролі протестантів у світі показує, що університети світового рівня, зокрема Гарвард, Прінстон, Єль, Оксфорд, Кембридж та Едінбург, були засновані та отримали розвиток як частина однієї із протестантських конфесій. Проте, беручи до уваги велику кількість духовних закладів освіти, ми можемо стверджувати, що це явище трансформується і відходить у минуле.

Висновки. Отже, взаємодія вірян-протестантів із суспільством зазнала змін, що особливо чітко відбивається на стані сучасної духовної освіти (навіть з урахуванням особливостей духовної освіти). Констатуємо, що не можливо реконструювати витоки явища українського протестантського антиінтелектуалізму, напрацювати інструмент розмежування загальносуспільного антиінтелектуалізму та власне протестантського.

Ми вважаємо, що подальшого та всебічного дослідження потребує духовна освіта в Україні, яка пройшла шлях від репресій до повноправної участі в освітньому просторі. Вважаємо, що за проведення подібних студій особливу увагу необхідно звернути на кілька цікавих соціологічних явищ, які супроводжували розбудову духовної освіти. Оригінальною розробкою автора є введення понять «конфесійні вимоги» та «конфесійні очікування», трансляція цих явищ на освітні процеси. 


\section{Jimepamypa}

1. Бінцаровський Д. Протестантизм без Реформації. Філософська дулка, 2013. № IV . С. 212-228.

2. В Україні відбулася перша габілітація докторської дисертації із богослов'я. Релігійно-інфорлаційна служба Украӥни : вебсайт. URL: https://risu.org.ua/ ua/index/all_news/culture/theology/66834 (дата звернення: 28.07.2020).

3. Висоновець О. Репресивна політика радянської влади щодо дітей вірних Євангельської християн-баптистської церкви в УРСР (60-80-ті pp. XX ст.). Релігія в Україні, 2015. URL: https://www.religion.in.ua/ main/history/28710-represivna-politika-radyanskoyivladi-shhodo-ditej-virnix-yevangelskoyi-xristiyanbaptistskoyi-cerkvi-v-ursr-6080-ti-rr-xx-st.html.

4. Всеукраїнський союз церков євангельських християн-баптистів. Офіційна вебсторінка : вебсайт. URL: https://www.baptyst.com/ (дата звернення: 28.07.2020).

5. Горбань Ю. Чи дійсно в Україні забагато університетів і що з ними робити? Укрінфорл : вебсайт URL: https://www.ukrinform.ua/rubric-society/2818883ci-dijsno-v-ukraini-zabagato-universitetiv-i-so-z-nimirobiti.html (дата звернення: 28.07.2020).

6. Дипломи духовних навчальних закладів України матимуть державне визнання. Релігійно-інфорлаційна служба України : вебсайт. URL: https://risu.org.ua/ua/index/all_news/culture/ theology/64053 (дата звернення: 28.07.2020).

7. До уваги випускників і працівників вищих духовних навчальних закладів. Офіиійний сайт Міністерства освіти та науки Украӥни : вебсайт. URL: https://mon.gov.ua/ua/news/usi-novivnipovidomlennya-2016-10-26-do-uvagi-vipusknikiv-ipraczivnikiv-vishhix-duxovnix-navchalnix-zakladiv! (дата звернення: 28.07.2020).

8. Євро-азійська акредитаційна асоціація. Офіuіŭна вебсторінка : вебсайт. URL: https://e-aаa.org (дата звернення: 28.07.2020).

9. Зацерківна М. Функції, структура й основи формування іміджу закладів вищої освіти. Вісник Харківської державної академї культури, 2018. URL: https://doi.org/10.31516/2410-5333.053.21.

10. Індикативна собівартість підвищить якість освіти. Освіта.UA (Вища освіта), 2020. URL: https://osvita.ua/vnz/71412/.

11. Київська богословська семінарія. Загальна інформація. 2020. Вебсайт. URL: https://www.ktsonline.org/.

12. Київський Християнський Університет. 2020. Вебсайт URL: https://www.kcu.org.ua.

13. Кундеренко I. Духовна освіта у протестантських навчальних закладах України: до проблеми формулювання понять. Освітній дискурс : збірник наукових праць. 2020. № 24. C. 99-110. URL: doi:10.33930/ ed.2019.5007.24(6)-8.

14.Кундеренко I. Протестантські духовні заклади вищої освіти як невід'ємна частина освітнього простору України. Актуальні питання гуманітар них наук : міжвузівський збірник наукових праць молодих учених Дрогобицького державного педагогічного університету імені Івана Франка. 2020. № 32. C. 254-262. URL: https://doi.org/10.24919/ $2308-4863.1 / 32.214516$.
15. Кундеренко І. Протестантські духовні заклади вищої освіти як невід'ємна частина освітнього простору України. Матеріали Всеукраїнської наукової конферениї лолодих учених і науково-педагогічних працівників (м. Умань, 16 червня 2020 року). С. 165-167.

16. Мокієнко М. Дисертація «П'ятидесятництво: особливості богословської та соціальної ідентифікації» : дис. докт. філос. наук: 09.00.14 / Нац. ун-т ім. Драгоманова. Київ, 2018. 488 с.

17. Опитувальна бесіда з Андрієм Гренком (керівником відділу освіти ВСЦ ЄХБ), проведена Іваном Кундеренком / особистий архів.

18. Опитувальна бесіда з доктором філософських наук Денисом Кондюком, проведена Іваном Кундеренком / особистий архів.

19. Опитувальна бесіда із Олександром Третяком (ректором Рівненської Духовної Семінарії та Академіï), проведена Іваном Кундеренком / особистий архів.

20. Панич О. Про оцінювання та забезпечення якості вищої освіти. [Електронний ресурс] osvita.ua. 2019. : вебсайт. URL: https://osvita.ua/vnz/64944/ (дата звернення: 28.07.2020).

21. Панич О. Зовнішня оцінка якості вищої освіти в Україні: що може бути змінено? 2015. Ocвітня політика : портал гроладських експертів. URL: http://education-ua.org/ua/articles/430-zovnishnyaotsinka-yakosti-vishchoji-osviti-v-ukrajini-shchomozhe-buti-zmineno.

22. Про затвердження переліку галузей знань і спеціальностей, за якими здійснюється підготовка здобувачів вищої освіти : постанова КМУ від 29.04.2015 № 266. URL: https://zakon.rada.gov.ua/laws/show/ $\mathrm{ru} / 266-2015-\%$ D0\% ВF (дата звернення: 28.07.2020).

23. Решетніков Ю. Статус богословської освіти в Україні в контексті подальшої гармонізації державно-конфесійних відносин. Актуальні проблели державного управління. 2013. Вип. 1. С. 132-137. URL: http://nbuv.gov.ua/UJRN/apdyo_2013_1_38 (дата звернення: 28.07.2020).

24.PО Таврійський християнський Інститут. Вебсайт. 2020. URL: https://tci.org.ua/.

25. Санніков С. Опитувальна бесіда із Сергієм Санніковим, $\mathrm{PhD}$, проведена Іваном Кундеренком. Особистий архів.

26. Синій В. Теорії про місійне покликання богословської освіти у пострадянському протестантизмі. Освітній дискурс. № 23. С. 78-92. Вебсайт. URL: doi: 10.33930/ ed.2019.5007.23(5)-7 (дата звернення: 28.07.2020).

27.У МОН розпочала роботу Комісія із державного визнання документів про наукові ступені та вчені звання про вищу духовну освіту. Офіuійний сайт Міністерства освіти та науки України : вебсайт. URL: https://mon.gov.ua/ua/news/usi-novivni-novini2016-09-08-zustrich-08-09-2016 (дата звернення: 28.07.2020).

28. Українець О. Антиінтелектуалізм як нова українська політика. Новини Івано-Франківська «Курс» : вебсайт. URL: https://kurs.if.ua/blog/ antyintelektualizm-yak-nova-ukrayinska-polityka (дата звернення: 28.07.2020).

29. Черенков М. Соціокультурний вплив ідей реформації на соціально-богословську ідентифікацію українського євангельського протестантизму. 
Мультиверсул. Філософський альланах : зб. наук. пр. Київ, 2008. Вип. 67. С. 3-10. URL: http://dspace.nbuv. gov.ua/handle/123456789/71779.

30. Щодо надання роз'яснення. Лист МОН України від 05.07.2018 № 1/9-421/ Міністерство освіти та науки України. URL: https://mon.gov.ua/ua/npa/listmon-ukrayini-vid-05072018-19-421-shodo-nadannyarozyasnennya (дата звернення: 28.07.2020).

31. Cavanagh S. Global Education Market Tops $\$ 4$ Trillion, Analysis shows. Edweek : вебсайт. URL: https://marketbrief.edweek.org/marketplace-k-12/ size_of_global_e-learning_market_44_trillion_analysis_says (дата звернення: 28.07.2020).

32. Martin M. Quality management in higher education: developments and drivers: results from an international survey. 2017. URL: http://www.iiep.unesco.org/en/quality-managementhigher-education-developments-and-drivers-resultsinternational-survey-9267.

\section{Анотація}

Кундеренко I. В. Соціологічні та іміджеві особливості забезпечення якості освіти серед протестантських закладів вищої освіти. - Стаття.

Більшість закладів вищої освіти України зі здобуттям незалежності мали пройти процес переосмислення та трансформації, винятком можна назвати лише новостворені ЗВО та так звані ПВНЗ.

Духовна освіта, яка від початку мала певні відмінності від світської освіти, повинна була не лише сформувати своє розуміння освіти зі всіма її складниками, але й пройти складний шлях від маргіналізації до визнання духовної освіти, тому найкращі напрацювання духовної освіти необхідно масштабувати. Особливо цікавий цей досвід трансформування соціальної групи із соціологічної точки зору, оскільки духовні ЗВО, створені протестантами, за 30 років пройшли шлях від маргіналізації до повноправної участі в освітньому просторі України.

Між авторами немає повної згоди стосовно антиінтелектуалізму. О. Українець, наприклад, описує загальносуспільне явище антиінтелектуалізму. Д. Бінцаровський, М. Мокієнко та інші розглядають наявність явища антиінтелектуалізму у протестантському середовищі. Ю. Решетніков, В. Синій студіюють становлення духовної освіти в Україні, заперечуючи своїм дослідницьким полем явище інтелектуалізму.

В інших публікаціях ми частково розглядаємо аспекти духовної освіти, а також питання термінотворення та недискримінаційного звертання до таких закладів освіти з метою уникнення маркування та стигматизації. Однак соціологічні та іміджеві особливості забезпечення якості освіти серед протестантських закладів вищої освіти не вивчені повністю. Мета статті - виокремити соціологічні та іміджеві особливості забезпечення якості освіти серед протестантських закладів вищої освіти.

Духовна освіта пройшла шлях від репресій до повноправної участі в освітньому просторі. Зокрема, звертається увага на кілька цікавих соціологічних явищ, які супроводжували розбудову духовної освіти. Також розглянуті соціологічні зміни, зумовлені сучасним станом духовної освіти та її особливостями. Оригінальною розробкою автора є введення понять «конфесійні вимо- ги» та «конфесійні очікування», трансляція цих явищ на освітні процеси. Стаття завершується аналізом розбіжності оцінок дослідників щодо 1) природи антиінтелектуалізму, 2) витоків і причин цього феномену, 3) поширення цього явища.

Автор доходить висновку, що не можливо реконструювати витоки явища українського протестантського антиінтелектуалізму, напрацювати інструмент розмежування загальносуспільного антиінтелектуалізму та власне протестантського. Ця теза знаходить кілька аргументів. Так, взаємодія вірян-протестантів із суспільством зазнала змін, що чітко прослідковується на стані сучасної духовної освіти (навіть з урахуванням особливостей духовної освіти). Констатуємо, що не можливо реконструювати витоки явища українського протестантського антиінтелектуалізму, напрацювати інструмент розмежування загальносуспільного антиінтелектуалізму та власне протестантського.

Ми вважаємо, що подальшого та всебічного дослідження потребує духовна освіта в Україні, яка пройшла шлях від репресій до повноправної участі в освітньому просторі. За умов проведення подібних студій особливу увагу необхідно звернути на кілька цікавих соціологічних явищ, які супроводжували розбудову духовної освіти. Оригінальною розробкою автора є введення понять «конфесійні вимоги» та «конфесійні очікування», трансляція цих явищ на освітні процеси.

Ключові слова: протестанти, вища освіта, антиінтелектуалізм, маркування, маргіналізація.

\section{Summary}

Kunderenko I. V. Sociological and image-related features of quality assurance of the education in faith-based educational institutions found by the Protestants. - Article.

Majority of the Higher Education system in Ukraine, once Ukraine became independent had to undergo a process of reconsidering its course and transformation.

This is not applicable however to the newly created and private owned educational institutions faith-based education and secular education has differences from the very beginning. Faith-based education in Ukraine had much more challenges, going beyond building vision for the education and all her components. Faith-based education encountered a need to grow from a marginalized existence to acknowledgment. Thus, best achievements of such vast developing approach to education is to be studied further and to be scaled.

So, sociologically such a transforming development that took place for the last 30 years has a tremendous research interest. Authors that describe anti-intellectualism among Protestants do not come to the same conclusions. O. Ukrainets, for example, describes anti-intellectualism as a sign of contemporary society. D. Bintsarovskiy and M. Mokienko study anti-intellectualism as within the context of specific Protestant subgroups. Yu. Reshetnikov, V. Syniy study the emergence of faith-based education in Ukraine, refuting anti-intellectualism as such even by the very field of their study.

In our own publication we partially look at some aspects of faith-based education, we access the terminology typically applied to faith-based education in Ukraine (coming to conclusion that at times certain terms used connotate stigmatization). At the same time we admit 
that sociological and image-related features of quality assurance of Protestant Education Institutions are not well studied. Purpose of this article is to determine some of the sociological and image-related feature of quality assurance of the education in faith-based educational institutions.

Faith based education in Ukraine evolved from underground existence under repressions to fully participating in the educational system of Ukraine. Author is addressing some sociological aspects that were involved in building faith-based education in Ukraine. Author is also addressing sociological changes to the Protestants of Ukraine. An original approach that author is taking is to introduce two distinctive terms: confessional requirements / demands and confessional aspirations, and applying those to educational processes. Article is concluded with assessment 1) nature of anti-intellectualism, traditionally ascribed to the Protestants of Ukraine, 2) reasons and origins of this phenomena, 3) scale of this phenomenon.

Author concludes that is it impossible to verify the source of Ukrainian anti-intellectualism among the
Protestants, equally it is impossible to develop a tool to distinguish general and specifically Evangelical antiintellectualism. All ideas come with proofs. Interaction of Protestant believers and society has been changing since Ukraine received Independence and it is most clearly seen when one studies faith-based education. Author argues that it is impossible to reconstruct the origins of the phenomenon of Ukrainian Protestant anti-intellectualism and equally so that is not possible to develop a tool for distinguishing between general anti-intellectualism and specific to a certain group anti-intellectualism.

Therefore, we suggest that further and comprehensive research of faith-based education in Ukraine is highly demanded. Author suggests that studies like that require special attention to several interesting sociological phenomena that accompanied the development of faith-based education. Author introduces two new terms "confessional requirements" and "confessional expectations".

Key words: protestants, higher education, antiintellectualism, putting labels, marginalizing. 